\title{
SOME RESULTS OF APPLYING DPSIR ANALYSIS FOR ULAANBAATAR AS PART OF THE SELENGE RIVER BASIN INTEGRATED WATER MANAGEMENT SYSTEM
}

\author{
D.Odontsetseg ${ }^{1}$ L.Janchivdorj ${ }^{1}$ G.Udvaltsetseg ${ }^{1}$ J.Frieden $^{2}$ \\ ${ }^{\prime}$ Institute of Geoecology, Mongolian Academy of Sciences, \\ gendvaa_u@yahoo.com \\ ${ }^{2}$ Australian Youth Ambassadors for Development
}

\begin{abstract}
Nowadays, ecological problems are being caused by economic aspects, and other hand economic issues are arising from ecological and environmental problems. Therefore, it is important to consider both social and economic factors, and take a basin approach to solving environmental problems. To find a relationship between economy and ecology, complex study of river basins is extremely important in establishing conditions for sustainable development in our country. This paper shows the results of applying DPSIR (Driver-Pressure-State-Impact-Response) analysis for Ulaanbaatar city, undertaken as part of a project on Integrated Water Management for the Selenge River Basin. The DPSIR analysis looks at the linkage between the economy and environment for the water quality and water resources of Ulaanbaatar. We used mDSS4 software to evaluate a range of management responses suggested by these issues and found that charging for pollution and measuring water use would have the largest overall impact on water quality and water resources respectively. The analysis was carried out for Ulaanbaatar, because it was identified as one of the key hotspot areas in the Selenge River Basin, which is the main river basin in Mongolia, in terms of both the economy and natural systems.
\end{abstract}

\section{Introduction}

The main goal of this analysis is to identify the main cause-effect relationship between human activities and the state of water quality and resources, and to find out responses for them. This is done using the DPSIR framework (Driving Force - Pressure - State Impact - State - Response), which was proposed by the European Environmental Agency (EEA, 1999). It has been adopted by many institutions around the world for assessing and reporting on the state of the environment and its interrelationships with human activity.

This paper focuses on the DPSIR analysis of Ulaanbaatar. This city is located in the Selenge River Basin, which is the biggest river basin of Mongolia in terms of both socioeconomic and environmental systems. The basin is also important on an international level since the Selenge River is the main tributary of Lake Baikal, the world's biggest fresh water lake. The condition of this world heritage lake depends on Selenge river water 
resources, and thus on the Mongolian economic and environmental situation.

For this reason, the Korea Environment Institute of South Korea has promoted a joint research project "Integrated Water Management of the Selenge River Basin" within the framework of the Network of Institutions for Sustainable Development (NISD), with Institute of Geoecology Mongolian Academy of Sciences, Baikal Institute of Nature Management Siberian Branch Russian Academy of Sciences, and UNEP Economic and Trade Branch.

As part of this project a number of research and field surveys have been conducted over the last 3 years throughout the Selenge River Basin in both the Mongolian and Russian part. During this research period we collected a range of water-related information, including data from the main branches of the economy such as livestock, mining, agriculture and social aspects such as demography, as well as water quality information. We then undertook DPSIR analysis in eight hotspot areas in the SRB. This paper presents the results of the analysis for Ulaanbaatar.

\section{Methodology}

The key socio-economic and environmental characteristics of Ulaanbaatar were described according to the DPSIR conceptual framework. To enhance clarity and understanding, Drivers, Pressures, and States and Impacts were considered separately for water quality and water resources.

Social, economic and environmental indicators for the Selenge River Basin established by a group of experts from Russia, Mongolia and South Korea, at the 9th Working Group Meeting of the Selenge River Basin Integrated Water Management Project in Seoul, May 2009. Data for the indicators applicable to Ulaanbaatar, collected by the Institute of Geoecology from a variety of sources, including the Mongolian Statistical Yearbook, field data and other available resources.

The mDSS4 computer package (Fondazione, 2006) was used to make Driver-Pressure-State chains and identify the main relationships between human activities and the state of water resources. These chains and their impacts were considered, and used to develop a range of potential management responses. The management responses evaluated by using mDSS4 (see Figure 1).

In particular, the software was used to construct an Analysis Matrix (AM) containing values of the indicator data. The AM presents the different management options and indicator values in the columns and rows of a matrix. To populate the matrix it was necessary to assess how the values of each indicator would change under each of the different management options. The software was then used to normalize the data to make the indicators comparable, creating an Evaluation Matrix (EM). This involved assigning a linear "cost" or "benefit" value function to each indicator, which rescaled all of the indicators to values between 0 and 1 . The indicators were then weighted according to their importance, allowing the software to calculate overall scores for each response to identify the best option. We used the SAW (simple additive weighting) decision rule (Fondazione, 2006). 
A "sustainability assessment" was used to investigate how the responses fared on social, economic and environmental criteria.

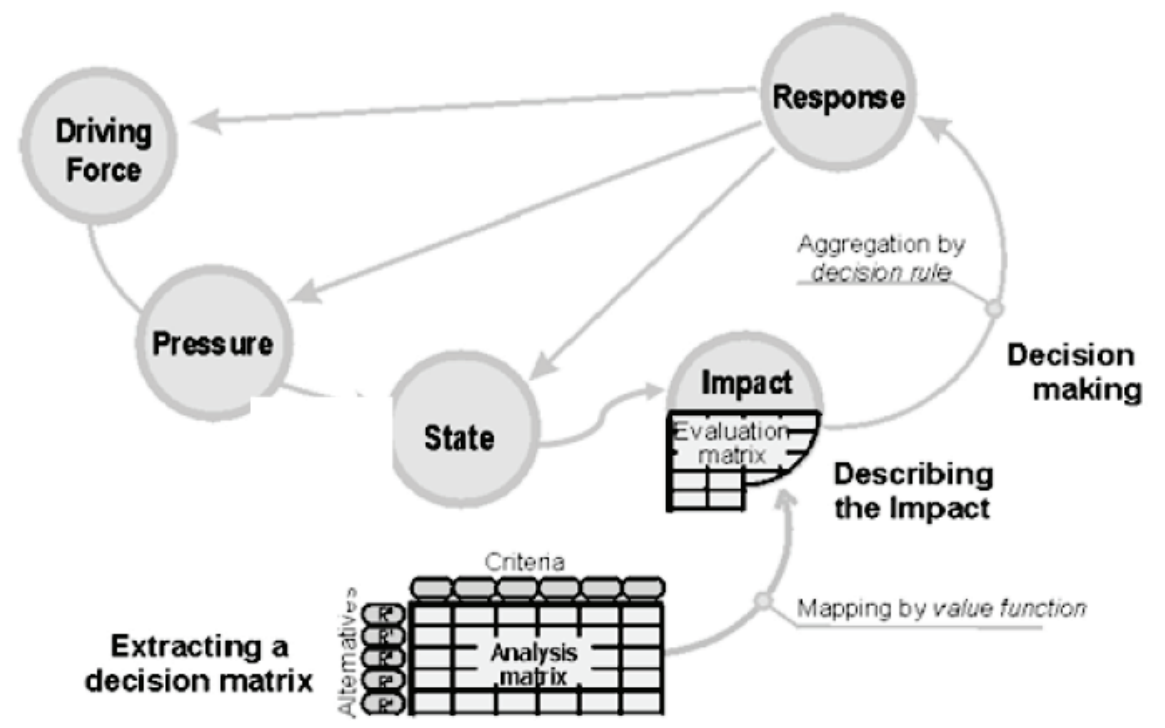

Figure 1: DPSIR framework and the mDSS4 analysis procedure (adapted from Giupponi, 2002)

\section{Results}

\section{Drivers and Pressures}

Driving forces are the processes and anthropogenic activities leading to pressures on the environment, while pressures are the direct stresses arising from the drivers and affecting the natural environment. This section considers the drivers and pressures affecting water quality and water resources in Ulaanbaatar.

\section{Water quality}

Environmental degradation in Ulaanbaatar is strongly linked to the growth of the Ger area, where people live in traditional Mongolian homes (felt tents called Gers) with poor infrastructure. The Ger area is not connected to the central water supply system and there is no treatment of waste from the area, causing severe water pollution. There are 126,400 pit latrines and same number of individual soak pits for disposing of grey water in the Ger areas. Waste water and wastes from the latrines and soak pits flow directly through the soil to the river basin.

The population of the Ulaanbaatar Ger area is currently growing at a rate of over $10 \%$ per year (Emerton, 2009). This growth is linked to the high rates of migration to 
Ulaanbaatar, which is largely due to the lack of infrastructure, services (e.g. health, education) and employment opportunities in remote areas. Harsh dzuds in the early years (1999-2003) also caused many herders to lose significant proportions of their livestock, and migrate to Ulaanbaatar.

Many of these migrants bring livestock with them from the countryside, causing further pressures on water quality. High levels of poverty and unemployment are also associated with other harmful practices. For example, air pollution from heating Gers impacts water quality through the hydrological cycle, while deforestation is also a continuing problem that impacts on water quality. The continued sprawl of the Ger area also means that the boundaries of Ulaanbaatar are constantly expanding and this change in land use also has associated negative impacts on water quality.

As well as air pollution resulting from heating Gers (with coal, wood and other materials such as old tires), the city's main source of electricity comes from three coal-fired power plants, which release large quantities of pollution into the atmosphere (CBD, 1996). The number of cars has also been increasing rapidly, both due to population growth and increasing affluence in parts of society. Many of these cars are imported second-hand, and badly maintained, which worsens their impact on the environment. The high heavy-metal content of fuel has also been linked to toxic emissions (CBD, 1996).

The transition to a market economy has seen Ulaanbaatar grow in importance as a hub for commerce and industry. It accounts for almost $70 \%$ of national production (Emerton, 2009), including almost 50\% of the nation's industrial production. Many large companies based in Ulaanbaatar draw on the central water supply systems and cause soil and water pollution by discharge of impure water. Small enterprises often discharge water directly into rivers.

Waste water treatment throughout the city is inadequate, largely to due to funding constraints (Altansukh, 2008). For example, the efficiency of the Central Waste Water Treatment Plant has been estimated to be around $60-70 \%$ due to poor maintenance, lack of spare parts, outdated equipment and frequent power shortages (Altansukh, 2008). Monitoring systems, moreover, are not sufficiently developed to police water pollution. Problems include the size of territory covered and the legislative and administrative environment.

Ulaanbaatar also currently lacks a solid waste (garbage) management system. Both collection and treatment of solid waste are insufficient and in some cases non-existent and this results in soil and water pollution.

\section{Water resources}

The rapid growth of the population of Ulaanbaatar has resulted in a rapidly increasing demand for water. As discussed earlier, this population growth is linked largely to migration into the capital city from other parts of Mongolia.

The centralized water distribution network is more than 50 years old and caters to less than half of the city's population (Emerton et al., 2009). Around 60\% of the popula- 
tion lives in Ger areas, and rely on water kiosks for their water supply.

A large amount of water wastage in areas connected to the central water supply system is caused by leaking pipes, with up to $30 \%$ of Ulaanbaatar's water use currently unaccounted (Emerton et al., 2009). It is often difficult to detect leakages in the water supply system, particularly since there are not many water use meters installed in the city.

Only around 20,000 $(<5 \%)$ of apartments have water use meters installed. Thus, many (apartment) households pay only for water supply, not usage, and have little incentive to save water. Recent data indicate that apartments with water meters use on average 60L/person/day less than those without water meters (Emerton et al., 2009).

Industrial water supply is also unmetered, and sourced entirely from fresh water resources. There is very little re-use of water in this sector due to limited economic incentives to do so. Because water charges are not linked to real water use there is no incentive to save water.

As discussed earlier, the importance of Ulaanbaatar as a commerce and industry hub is also an important driving force affecting water resources in the city. Again, factors such as economic and industrial production rates have important influences on the way the city uses and manages its water. The number of businesses in Ulaanbaatar has increased by $26 \%$ in the past four years, and continued growth is projected (Emerton et al., 2009)

\section{States and Impacts}

Under the DPSIR framework, the state refers to the environmental conditions of the natural system. The impact is the measure of the effects due changes in the state of environmental system. This section considers the state of water quality and water resources in Ulaanbaatar, and the impacts of these conditions.

\section{Water quality}

The Tuul River Basin is now considered the most polluted river basin in Mongolia (Emerton, 2009). Field work carried out in 2007 and 2008 found significant levels of pollution in parts of the Tuul River downstream of Ulaanbaatar (Mun et al., 2008). Samples were found to be polluted with arsenic, and water downstream of the WWTP also had a foul smell, very low dissolved oxygen and high conductivity (Enkhtuya, 2009). Some of the impacts associated with rising air pollution include rising $\mathrm{SO}_{2}$ content of snow, and impacts on the $\mathrm{pH}$ of rainfall (CBD, 1996).

Poor water quality has been linked to a range of human health problems in Ulaanbaatar. Of the 10,000 cases of diarrhea reported annually in Mongolia, 70\% occur in Ulaanbaatar (Basandorj and Davaa, 2005). Dysentery and hepatitis stemming from a lack of access to safe drinking water and sanitation are also common in the city, while contamination with heavy metals such as arsenic has the potential to be deadly. Of particular concern is the fact that some Ger area residents use water from shallow wells, springs and other watercourses which often do not meet drinking water standards. 
Decreases in water quality also have negative impacts on aquatic and related ecosystems.

\section{Water Resources}

Water is supplied by the Ulaanbaatar Water Supply and Sewage Company (USAG) from four ground water sources: at the confluence of the Terelj and Tuul rivers ("Upper"), and at three locations in the city. The water supply system is currently operating at around $70 \%$ capacity, and recent estimates suggest that the Ulaanbaatar could be facing severe water shortfalls by 2020 (Emerton et al, 2009). Seasonal water shortages between May and August have already been observed.

As can be seen from Table 1, the power plants account for around $25 \%$ of daily water use. By contrast, Ger area water users (around $60 \%$ of the population of Ulaanbaatar) account for only $2 \%$ of annual water use or around $4 \%$ of household water use. Apartment dwellers are the largest category of water users, despite comprising only around $40 \%$ of the city's population. Thus, a key issue for Ulaanbaatar is the current inequitable supply of water resources.

Table 1

water use by sector, Ulaanbaatar (Emerton et al, 2009)

\begin{tabular}{|l|r|r|r|}
\hline \multicolumn{1}{|c|}{ Sector } & \multicolumn{1}{c|}{$\begin{array}{c}\text { Volume } \\
\left(\mathbf{1 0}^{\mathbf{6}} \mathbf{m}^{3} / \mathbf{y e a r}\right)\end{array}$} & \multicolumn{1}{c|}{$\begin{array}{c}\text { Volume } \\
\text { (\% Total) }\end{array}$} & \multicolumn{1}{c|}{$\begin{array}{c}\text { Tariff } \\
\text { (Tug/m3) }\end{array}$} \\
\hline Industries & 2.3 & $3 \%$ & 329.32 \\
\hline Business and commercial & 8.29 & $11 \%$ & $\mathrm{n} / \mathrm{a}$ \\
\hline Other institutions & 2.67 & $3 \%$ & $\mathrm{n} / \mathrm{a}$ \\
\hline Power plants & 18.36 & $24 \%$ & 909.09 \\
\hline Irrigated farms & 1.5 & $2 \%$ & 167.27 \\
\hline Livestock production & 1.37 & $2 \%$ & \\
\hline Ger settlements & 1.7 & $2 \%$ & \\
\hline Apartment dwellers & 40.87 & $53 \%$ & $0 \%$ \\
\hline Individual houses & 0.22 & $0 \%$ & \\
\hline Total & $\mathbf{7 7 . 2 8}$ & $\mathbf{1 0 0 \%}$ & \\
\hline
\end{tabular}

Water tariffs are low and inequitably distributed (see Table 1), with people in Ger settlements paying more than those in apartments, despite generally having lower incomes. Water use in Ger areas is only 7-9L per person per day, which is far well below the amount needed to meet basic health and hygiene requirements. Water is largely obtained from kiosks in Ger settlements (supplied by pipeline or tanker) and collecting water can entail long walks carrying water canisters. Some Ger area residents continue to use shallow wells and watercourses (springs, streams, rivers) to access water (Emerson et. al, 2009), and this can have negative impacts on health. 


\section{Responses: assessment of different options using mDSS4 software}

12 management responses (Table 2) were evaluated using mDSS4 software. Some responses addressed issues related primarily to either water quality or water resources, while others can be seen to address both.

Table 2

Management Responses for DPSIR analysis of Ulaanbaatar

\begin{tabular}{|c|c|c|}
\hline Response - short name & Response description. & Response addresses: \\
\hline No Change & No change in policy or actions. & $\mathrm{n} / \mathrm{a}$ \\
\hline Charge All Water Users & $\begin{array}{l}\text { Change law so that all water users must pay for } \\
\text { water. Currently some users do not pay for water, } \\
\text { by law. }\end{array}$ & Water resources \\
\hline Charge For Pollution & Introduce a charge for water pollution. & Water quality \\
\hline Decrease Leakage & $\begin{array}{l}\text { Decrease leakage of pipes. Water supply system has } \\
\text { many leakages. This response involves fixing these. }\end{array}$ & Water resources \\
\hline Ger Area Water Supply & Expand centralized water system to Ger area. & Water resources \\
\hline Measure Water Use & $\begin{array}{l}\text { Measure water use, and charge accordingly. } \\
\text { Payment should be related to how much water is } \\
\text { used. }\end{array}$ & Water resources \\
\hline Re-use Industrial Water & $\begin{array}{l}\text { Re-use industrial water. Decrease the quantity of } \\
\text { fresh water used by industry through reusing water. }\end{array}$ & $\begin{array}{l}\text { Water quality; water } \\
\text { resources }\end{array}$ \\
\hline Ger Area Sanitation & $\begin{array}{l}\text { Introduce waste treatment facilities in Ger area. } \\
\text { Currently there is no waste treatment in Ger areas. } \\
\text { This option would introduce sanitation services in } \\
\text { Ger areas. }\end{array}$ & Water quality \\
\hline $\begin{array}{l}\text { Millennium Goal Water } \\
\text { Supply }\end{array}$ & $\begin{array}{l}\text { To focus water management on reaching the } \\
\text { millennium goal for minimum 25L of water/person/ } \\
\text { day water supply. }\end{array}$ & Water resources \\
\hline Decrease Ger Area & To decrease the Ger area in Ulaanbaatar. & $\begin{array}{l}\text { Water quality; water } \\
\text { resources }\end{array}$ \\
\hline $\begin{array}{l}\text { Build local distributed } \\
\text { WWTPs }\end{array}$ & $\begin{array}{l}\text { Build distributed Waste Water Treatment Plants at } \\
\text { pollution sources. }\end{array}$ & Water quality \\
\hline $\begin{array}{l}\text { Control System Under } \\
\text { Inspection Agency }\end{array}$ & Build a control system under the inspection agency. & Water quality \\
\hline Solid Waste Mgt System & $\begin{array}{l}\text { Decrease the amount of solid waste by establishing } \\
\text { a Solid Waste Management System. }\end{array}$ & Water quality \\
\hline
\end{tabular}

Table 3, below, shows the indicators that were used to assess these responses. 
Table 3

Indicators* used to assess the different management responses in Ulaanbaatar

\begin{tabular}{|c|c|c|c|}
\hline Drivers & Pressures & States & Impacts \\
\hline $\begin{array}{ll} & \text { Agricultural } \\
\text { production } \\
\text { - } & \text { Economic growth } \\
& \text { rate } \\
\text { - } & \text { Economically } \\
\text { active population } \\
\text { - } & \text { Forest area/capita } \\
\text { - } & \text { Industrial } \\
\text { - } & \text { production } \\
\text { Migration } \\
\text { Number of } \\
\text { houses } \\
\text { Population } \\
\text { density } \\
\text { Rate of growth of } \\
\text { Ger area }\end{array}$ & $\begin{array}{ll}- & \text { Impervious paved } \\
\text { area } \\
\text { - } \quad \text { Land-use change } \\
\text { Municipal/ } \\
\text { domestic water } \\
\text { demand } \\
\text { Waste water } \\
\text { discharge }\end{array}$ & $\begin{array}{l}\text { - } \\
\text { Achievement of } \\
\text { ambient water } \\
\text { quality standard } \\
\text { Change of } \\
\text { ecosystem/benthos } \\
\text { and plankton } \\
\text { Groundwater } \\
\text { withdrawal } \\
\text { - } \quad \text { Household water use } \\
\text { River environmental } \\
\text { flow } \\
\text { Water quality of } \\
\text { rivers, streams, } \\
\text { reservoirs } \\
\text { Water supply rate }\end{array}$ & 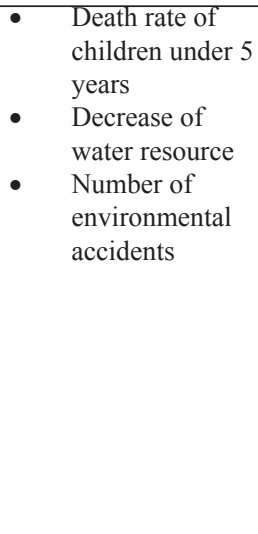 \\
\hline
\end{tabular}

Results of the analysis are shown in Table 4 below. Figure 2 shows the sustainability analysis of the various options (i.e. how they perform on social, environmental and economic criteria).

Table 4

Results of MDSS4 evaluation of management responses for Ulaanbaatar

\begin{tabular}{|l|c|c|}
\hline Option & Score & $\begin{array}{c}\text { Percentage score } \\
\text { (Relative to 1 }\end{array}$ option) \\
\hline Charge For Pollution & 0.6109 & $100 \%$ \\
\hline Solid Waste Management System & 0.5697 & $93 \%$ \\
\hline Control System Under Inspection Agency & 0.5366 & $87 \%$ \\
\hline Build local distributed WWTPs & 0.5065 & $82 \%$ \\
\hline Measure Water Use & 0.4890 & $80 \%$ \\
\hline Re-use Industrial Waste Water & 0.4690 & $76 \%$ \\
\hline Ger Area Sanitation & 0.4419 & $72 \%$ \\
\hline Decrease Ger Area & 0.4389 & $71 \%$ \\
\hline Charge All Water Users & 0.4382 & $71 \%$ \\
\hline Ger Area Water Supply & 0.3423 & $56 \%$ \\
\hline Millennium Goal Water Supply & 0.3370 & $55 \%$ \\
\hline Decrease Leakage & 0.3320 & $54 \%$ \\
\hline No Change & 0.3288 & $53 \%$ \\
\hline
\end{tabular}




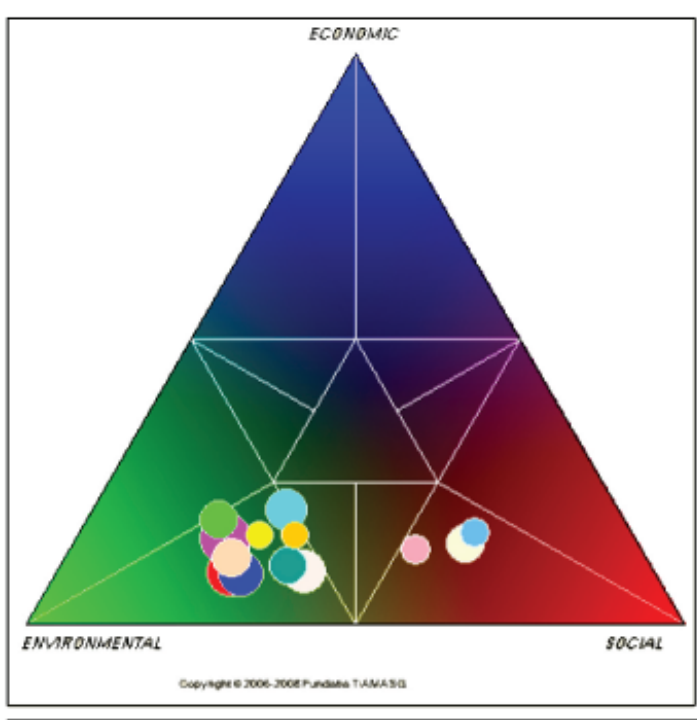

Figure 2: Sustainability analysis of DPSIR analysis for Ulaanbaatar.

\section{Conclusions}

The DPSIR analysis has highlighted the complexity of the issues facing water managers in Ulaanbaatar, and the way that different driving forces and pressures create negative impacts on both people and the environment.

Charging for pollution was found to be the best management option of those considered, followed by Implementing a Solid Waste Management System. Interestingly, these management responses both address water quality concerns. Measuring water use is the $5^{\text {th }}$ best option, but the highest performing of the options focused on water resource issues. Perhaps most significantly, the 'business as usual' option of not undertaking any management actions was found to be the worst possible option.

Sustainability analysis of the various options shows that they all perform most strongly on environmental criteria and least well on economic criteria. The Millennium goal water supply, Ger area water supply and Decrease Ger area options performed most strongly on social criteria, while measuring water use performed best on economic criteria.

It is worth noting, however, that the results rely heavily on subjective assessments of how indicator values might change under different management actions. Moreover, because of the nature of the DPSIR process, some important factors, such as the costs of different responses, were not included in the mDSS model.

Despite this, the DPSIR/mDSS process proved very helpful in allowing a range of 
factors and their interrelationships to be considered. Indeed, the mDSS package was designed primarily to facilitate understanding, collaboration and public participation in integrated water management (Fondazione, 2006). One of its main values lies in its ability to clarify and explore different stakeholders' opinions about the nature of environmental issues, and possible responses.

This project is therefore an important step towards understanding the complex social, economic and environmental factors that underlie the water management challenges facing Mongolia today. Gaining input from stakeholders and decision-makers could in future be used to reduce the uncertainties associated with the approach, and highlight areas that are particularly contentious.

Overall, the DPSIR process has provided a useful framework for highlighting the linkages between different parameters, and allowing social, economic and environmental factors to be explicitly considered in decision making. It is hoped that as well as providing recommendations for future management of water resources and quality in Ulaanbaatar, these results will help guide integrated water management in the Selenge River Basin, and other river basins of Mongolia.

\section{References}

1. Altansukh, O. "Surface water quality assessment and modelling: a case study of the Tuul River, Ulaanbaatar, Mongolia.” 2008. Master's Thesis, available online August 2009 at: www. itc.nl/library/papers_2008/msc/wrem/altansukh.pdf

2. Basandorj, D. and G. Davaa.. Mongolian National Case Study - Reference to Tuul River Basin. Case Study prepared for the 2nd World Water Report by UNESCO Office Beijing in collaboration with World Water Assessment Programme, UNESCO Paris and Mongolian National IHP Committee, Ulaanbaatar. 2005

3. CBD, "Convention on Biological Diversity Strategy and Action Plan - Mongolia", Ulaanbaatar. 1996, Available online August 2009 at: www.cbd.int/doc/world/mn/mn-nbsap-01-p2-en. pdf

4. European Environmental Agency, Environmental indicators: typology and overview. Technical Report no. 25, 1999

5. Emerton, L, Erdenesaikhan, N, de Veen, B, Tsogoo, D, Janchivdorj, L, Gavaa, G, Suv daa, Enkhtsetseg, Dorjsuren, Ch, Sainbayar, D and Enkhbaatar, A. "The Economic value of the Upper Tuul ecosystem, Mongolia: draft report" 2009.

6. Enkhtuya, M. "Assessment of Selenge River Water Quality in Mongolia by DPSIR approach" Seoul. 2009

7. Fondazione Eni Enrico Mattei. “mDSS4 USERS’ Guide.” Italy, 2006.

8. Guiponni, C., 'From the DPSIR reporting framework to a system for a dynamic and integrated decision making process.' Paper presented at MULINO Conference on "European policy and tools for sustainable water management", Venice, Italy. 2002. Available online August 2009: http://siti.feem.it/mulino/dissem/intcon/giuppon.pdf

9. Mun, Y., Ko, IH., Janchivdorj, L., Gomboev, B., Kang, SI., Lee, C-H., "Integrated Water Management Model on the Selenge River Basin: Status Survey and Investigation (Phase I)", Korea Environment Institute, Seoul. 2008. 